Southern Illinois University Carbondale

OpenSIUC

Articles

Department of Criminology and Criminal Justice

2010

\title{
Gendered Imprisonment in Japan: An Examination of Imprisonment for Stimulant Drug Offenses
}

Christopher W. Mullins

Southern Illinois University Carbondale, mullinsc@siu.edu

Garrett Grothoff

Follow this and additional works at: http://opensiuc.lib.siu.edu/ccj_articles This is an Author's Accepted Manuscript of an article published in International Journal of Comparative and Applied Criminal Justice, Vol. 34, No. 2 (2010) (copyright Taylor \& Francis), available online at: http://www.tandfonline.com/10.1080/01924036.2010.9678834.

This Article is brought to you for free and open access by the Department of Criminology and Criminal Justice at OpenSIUC. It has been accepted for inclusion in Articles by an authorized administrator of OpenSIUC. For more information, please contact opensiuc@lib.siu.edu. 
Gendered Imprisonment in Japan

Christopher W. Mullins

and

Garrett Grothoff

Criminology and Criminal Justice

Southern Illinois University Carbondale

Please direct all correspondence to Christopher W. Mullins, Department of Criminology and Criminal Justice, 4226 Faner Hall, Mail Code 4504, Southern Illinois University Carbondale, Carbondale IL 62901. 


\begin{abstract}
Japan is well known as a society that has not only low crime rates but also for using incarceration sparingly, sending few convicted offenders to prison. Yet, certain crimes, such as drug offenses, receive little leniency in the Japanese criminal justice system. Johnson (1996b) found empirical support for both a chivalry and evil woman effect in the system's treatment of female drug offenders. This paper reexamines and extends the core issues in Johnson's (1996b) exploration of women's imprisonment in Japan. It traces the patterns in female incarceration where data is available from the post-war period until 2004. It specifically examines the incidences of incarceration of women for stimulus drug offenses and identifies key correlates on the macro-level associated with changes in imprisonment practices.
\end{abstract}


Japan is well known as a society that has not only low crime rates but also low incarceration rates, sending few convicted offenders to prison. Further, with the large amount of discretion inherent within Japanese prosecution and a tendency to suspend prosecution in many cases, only select cases go to formal trial. Even there, leniency is often extended to those who show remorse and the willingness to change behavior (Johnson 1996a). This produces a comparatively small rate of incarceration. In 2004, Japan's imprisonment rate for convicted offenders was 50.85 per 100,000 (Ministry of Justice, Japan, 2005). In 2004 the US rate was 725 per 100,000 (US Department of Justice 2005), roughly 14 times greater.

There are two structural locations within the Japanese criminal justice system where leniency enters: the prosecution and the judge. Once a case is brought to a prosecutor, the prosecutor has a number of options available. First, the prosecutor can simply discharge the case via non-prosecution. This is the US equivalent of a prosecutor not filling charges. In Japanese non-prosecution, the case is deemed problematic due to issues of evidence, the complaint, the mental sanity of the offender or other aspects. Second, the prosecutor can suspend prosecution. Here the prosecutor acknowledges a strong enough case to bring forward but deems moving forward unnecessary. It is through these two mechanisms that prosecutors can filter cases, allowing more informal control processes (apologies, etc) to settle the issue at hand or otherwise resolve an issue without the formal involvement of the courts (Araki 1985, Johnson 1998, 2002, UNAFEI 2005). The other major source of leniency in the system is judicial sentencing.

Following continental systems, judges in Japan decide guilt and sentence simultaneously. Less than $1 \%$ of cases brought to trial produce a not-guilty finding; yet, as Japan does not use 
plea bargaining ${ }^{1}$ over $90 \%$ of those cases brought to trial are undisputed. If one looks only at the disputed cases (i.e., where the defendant contests the charges against him or her) acquittal rates range from 1 to $4 \%$ depending on the year and the court (UNAFEI 2005). While there are statutorily prescribed penalties under Japanese law, judges have a wide amount of discretion in the penalties they apply. Just as prosecutors can suspend charges, judges can likewise suspend sentences, which they do with frequency. For example, in 2002, 66.7\% of sentences applied were suspended (Japanese Ministry of Justice 2003). Even when an offender is sentenced to imprisonment, sentences tend to be short. Of those sentences handed down in 2002, 93.5\% were for less than three years; $21.5 \%$ were for a year or less. It should also be noted that most individuals sentenced to prison are recidivists (Japanese Ministry of Justice 2003) ${ }^{2}$. These factors, combined with lower comparative crime rates, contribute to a low rate of incarceration.

There are limits to this leniency. David Johnson $(1998,2002)$, in his research on Japanese prosecution, found that there are two major places where the state turns toward harsher punishment: recidivist offenders and drug offenders. Drug offenders are particularly seen as being incapable of rehabilitation; a prosecutor explained to Johnson (2002: 196) "We don't try to rehabilitate them....No one can. Drug users are dangerous criminals, threats to the social order, and they ought to be treated as such." Such views are readily apparent in any statistical examination of crimes for which Japanese citizens are incarcerated. Essentially all scholars and commentators on Japanese culture in general and their law and criminal justice system specifically discuss the profound emphasis on the concept and practice of social order. As we will show later in the paper, a primary focus of Japanese imprisonment focuses on drug

\footnotetext{
${ }^{1}$ A Japanese judge is not allowed to sentence solely based upon a confession. There must be evidence that sustains the truthfulness of the offender's confession.

${ }^{2}$ Many observers, however, point out that the conditions within and treatment of offenders within Japanese prisons is harsher than those in the US or Western Europe (Araki 1985, Johnson 2002).
} 
offenders, with the rate of suspensions for drug crimes, especially stimulus drug offenses, being incredibly low.

As with essentially every other modern industrial or post-industrial society, Japan’s official crime and criminal justice data exhibit a profound gender gap. Far and away men are severely over represented in Japanese prisons. Yet, there are female offenders who, as Johnson (1996b) pointed out, are overwhelmingly incarcerated for violations of stimulus drug laws. The rate of female incarceration in Japan increased substantially during the 1970s and 1980s at the same time men's rates were decreasing. In his exploratory analysis, Johnson (1996b) examines whether or not Japanese women receive preferential treatment with criminal justice processing (a ‘chivalry' influence) or experience an 'evil woman' effect (where by women are treated more harshly due to their criminality being defined as a double deviance-see Chesney-Lind and Pasko 2004; Daly 1994). He concludes that while women receive preferential treatment in the criminal justice system, so do men. As discussed above, leniency is deeply rooted within the system. Once women get to sentencing, especially those who have prior convictions, Johnson argues that they experience an 'evil woman' effect, with a lower likelihood of suspension and longer sentences given. Insightfully, this work establishes the presence of a gender bias within the system, yet it does not look at variation within this pattern of institutional behavior, nor does it seek to empirically connect that variation with other social conditions or forces. We see Johnson's (1996b) work as the starting point for our analyses here.

\section{Gender in Japan}

Any examination of gendered imprisonment in Japan must be grounded within the specific social structure and experiences of Japanese society. The historically patriarchal nature 
of Japanese society is well known (see for example Stanley 2007); much recent writing has been devoted to the exploration of changing (or the lack thereof) gender roles and positions in postWorld War II society. Legal and constitutional changes have provided women with political, economic, educational and social equity (Morely 1999; Vavich 1998) yet actual treatment and internalized gendered scripts and attitudes lag behind the law itself. Still today, the strongest form of emphasized femininity for Japanese women is wifedom and motherhood. While the representation of women in Japanese higher education and the general workforce has dramatically increased in past decades, there is still strong sex segregation within these institutions. Even though more women are obtaining post-secondary education, women's enrollment are focused in the relatively new two-year college system, leaving the traditional four year university as male dominated terrain. Similarly, occupational categories are strong sextyped with a substantial gender gap in earnings. Further, women's career paths are strongly different from men's, with a strong cultural expectation of retirement upon marriage (Lambert 2007, Morley 1999, Ochiai 1998, Uno 1998, White 1998a, 1998b).

Such a strong subordination of women within the society does create a fertile ground for a potential 'evil woman' effect within the criminal justice system. The strong cultural push toward the marginalization of women into the domestic sphere will reduce over all female offending due to the knifing off of criminal opportunities (see Miller and Mullins 2006; Warr 2002). No doubt, this creates and maintains a portion of the gender gap in Japanese offending. In turn, this social segregation will enhance negative perceptions of those women who do engage in crime, making the doubly deviant nature of women's offenses (see Daly 1994) all the more intense. This combination of factors could influence both prosecutors and judges in their granting (or the lack thereof) of leniency. 
Such gender issues and trends are important to understand the contextual nature of the variation in Japanese women's imprisonment. If one accepts the premise that incarceration is a form of social control often directed at undesirable or other populations which are deemed to need control (see Haley 1991, 1998 for an argument specific to Japan; see Reiman 2007; Shelden2001 for a general examination), the amount of control 'required' should vary with social conditions such as labor market tightness, political competition and other social forces. In the context of this paper, we would suggest that incarceration is one way of controlling women in modern Japan. It is possible that the amount of leniency experienced (or the strength of the double deviance effect) will vary based upon the amount of social threat that Japanese women pose to Japanese men in the public sphere. Thus if a labor market tightens or if women make strong advances in political representation, this can create a social pressure to increase female incarceration as a form of backlash. In times of economic prosperity, the pressures to control women might lessen, producing lower incarceration rates.

This paper reexamines and extends the core issues in Johnson's (1996b) exploration of women's imprisonment in Japan. It traces the patterns in female incarceration where data is available from the post-war period until 2004. It specifically examines the incidences of incarceration of women for stimulus drug offenses and identifies key correlates on the macrolevel associated with changes in imprisonment practices. It is exploratory in nature, seeking to identify associations and relationship for future explanatory examinations.

\section{Methods}

\section{Data}


Data come from the analysis of the Ministry of Japan's White Paper on Crime. The White Paper on Crime is a compilation of statistics submitted by various agencies across Japan and condensed into a single instrument. Included in these are the National Police Agency, Annual Report of Statistics on Prosecution, Annual Report on Judicial Statistics, Annual Report of Statistics on Corrections, Annual Report of Statistics on Rehabilitation, and the Annual Report of Statistics on Immigration Control. The Japanese Correctional Institution system is comprised of prisons, juvenile prisons, juvenile training schools, detention houses, and juvenile classification homes. Collectively these are referred to as penal institutions. Seventy-four penal institutions exist, as of April 1, 2004, and of these fifty-nine are prisons, of which six are all female.

Data representing the trends in stimulant drug offenses show the number of persons cleared by the police for stimulant drug law violations and violations of the Narcotic Provisions Law related to stimulant drugs. Stimulant drug law violations are classified by smuggling in/out, illicit production, possession, providing/receiving, using, and others. Data was used from 1955 through 2004 in five year intervals.

The data are yearly totals ranging from 1946 through 2004 . The data is compiled from the entire Japanese prison population. It is then categorized by offense into eight sections: Penal Code, Special Law, Traffic, Drug, Financial and Economic, Election-Related, High Technology, and Firearm. These categories are then subdivided into: specific offenders, offenders with criminal histories, comparison of trends with other countries, and overseas offenses committed by and against Japanese nationals. The primary focus of data collection stemmed from offenses reported and offenders cleared. The data includes male and female offenders. The present data represents rates of Japanese offending and corrections statistics per 100,000 persons. 
Other data were taken from the Japanese Ministry of Internal Affairs and Communication's Statistics Bureau, especially the Historical Statistics of Japan compilation (Japanese Ministry of Internal Affairs and Communications 2009). These data include work force participation rates for both men and women, unemployment rates for men and women, average hours worked per week for men and women, and secondary education attainment for men and women (measured as total percentages enrolled as well as disaggregating women's attendances into junior colleges and universities ${ }^{3}$ ). We also collected data on the percentage of assembly members who are female. These data are intended to measure both general economic health issues as well as women's socio-economic status. From here, we will examine some basic trends over time in incarceration rates for those convicted of stimulus offenders.

\section{Findings}

\section{Trends}

As mentioned above, there is a large gap within incarceration rates between men and women within Japanese society. Figure 1 displays over time the incarceration rate for men and women per 100,000 in the population. The male rate is clearly generally downwards, with the exception of a brief surge during the 1980s. At this scale, the female line looks fairly flat and invariant.

[Figure 1 about here]

If one looks at the same female trend line more closely one sees that it is much more variant than the male line with no overall trend. As Figure 2 shows, while female incarceration

\footnotetext{
${ }^{3}$ During the time period examined in the study Japan created a series of community colleges whose curricula are aimed at women, training them for both pink collar jobs and assumption of wife status. See Morely 1999 for a full discussion of sex segregation in enrollments at differing types of Japanese secondary education.
} 
follows the general downward trend in the immediate post-war period, it has much greater fluctuation over time afterward. While it too shows an increase during the 1980s, it has another peak in the early 1960s and a generally upward trend through the late 1990s and into the current decade.

[Figure 2 about here]

Overall, only a small percentage of stimulus offenses are suspended at the prosecution stage. This produces a large population of offenders being incarcerated for this offense. Figure 1 shows the percentage of all new prison admissions per year that were for stimulus offenses.

[Figure 3 about here]

In the immediate post-war environment, incarceration for stimulus violations was high, but quickly fell to a very small proportion of those being incarcerated. Subsequently, beginning in the early 1970s, Japan saw a major increase in the proportion of offenders being remanded to incarceration for stimulus offenses. This high level of representation within all prison admissions remains the norm throughout the 1980s and 1990s with some variation, with stimulus offenders accounting for a reduced proportion of offenders sentenced to incarceration during the first few years of the new millennium.

It is also instructive to examine this trend within each sex as well. Figure 3 shows, by year, the percentage of all new male prison admissions who are incarcerated on stimulus drug violation. Through the 1970s and into the 1980s, stimulus offenders become a larger portion of the total number of new admissions. Through the 1990s there is year to year variation but the percentage varies within the mid-20s, but never exceeds $30 \%$ of all new offenders. 
[Figure 4 about here]

Figure 4 shows the proportion of all new female admissions to prison who are stimulant offense violators. While the trend line is similar, note that the magnitude is much greater. Throughout the 1980s and 1990s over half of all women newly admitted to prison in Japan were sentenced for stimulus violations.

[Figure 5 about here]

One reason that stimulus violations constitute a large portion of both male and female admissions to prison is the low rate of stimulus case suspensions. Figure five shows the rate of cleared cases which are prosecuted.

[Figure 6 about here]

Except for a brief lacuna of stimulus prosecutions in the 1960s, those who appear before a court for violations of the stimulus laws are more likely to be prosecuted than for most any other crime (the only exception being motor vehicle violations, which are qualitatively different in nature and tend not to lead to incarceration).

Examining these trends highlight two general patterns. First, male and female incarceration tends to vary independently of each other. Examining the rates at which men and women are sentenced to incarceration show clearly different trend lines. Males experience a general reduction in the use of incarceration during the period under examination, while females experience much more variation in the implementation of incarceration sentences. Second, incarceration for stimulus offenses does not appear to be sex-variant during the period explored here. While a greater portion of women compared with men who are incarcerated are done so for 
violations of stimulus offenses, and a greater number of men are incarcerated for stimulus drug violations, the fluctuation in the overall trends is very similar.

\section{Exploratory Analysis}

As mentioned in the introduction, the Japanese criminal justice system sees drug law violations, especially stimulus drug violations, as a serious matter. This is why the rate of prosecution suspension is so low. Yet, as the above trends show, the level of stimulus offenders sentenced to prison has been variable over time. Here we will explore whether or not any of this variation is associated with broader social trends, especially those related to gender. If Johnson (1996b) was correct, an 'evil woman' effect could be stimulated or enhanced by a backlash against women's increasing social and economic opportunities. On the macro-social level, changes in women's (and men's) economic positions might influence the way in which women (and men) are treated within a criminal justice environment. Contracting labor and wage markets might exert an influence upon penal institution decision making, creating a climate which favors incarceration, especially for those crimes which incarceration is all ready used with great frequency. Similarly, women's advances in workplace participation might exert pressure upon men's labor market experiences, generating a backlash effect on female stimulant offenders.

While there are not enough data on all cases to have confidence in regression analyses, correlations can identify relationships between incarceration data and socio-economic conditions. Table 1 shows the results of correlation analysis of the key variables in question here. The strongest relationships ware between male and female stimulus admissions. Comparing the disaggregated rates to each other, the relationship is almost perfect. The Pearson coefficient is 
.925 at a .000 significance level. In and of itself, this raises serious questions about any genderspecific explanation of female stimulus incarceration.

[Table 1 about here]

Most of our specific measures of women's social positions (i.e., educational attainment, assembly representation, labor force participation) do not produce statistically significant relationships with stimulus incarceration. Looking at female incarceration overall there is a strong negative association between female incarceration and female labor participation. A backlash hypothesis would predict the opposite sort of association. Further, there is a similar (though not quite as strong or as statistically significant) relationship with male incarceration and female labor force participation. This suggests that female labor force participation is a better measure of overall economic factors than as a measure of female equity. Taken as a whole, at least with these measures, there does not seem to be a strong backlash use of criminal justice as a response to increases in female social equity.

In general, there is an association between general economic health and incarceration for both men and women. Male and female unemployment, strongly intercorrelated themselves, are positively correlated with male and female incarceration overall and stimulus incarceration specifically. This shows a potential interaction between general economic conditions and stimulus use (or at least arrest and incarceration) that needs much more exploration and examination. These correlational findings are partial and we only present them tentatively to shed light on potential interrelationships. More complete incarceration data is required to say anything more solid.

\section{Discussion and Conclusions}


In the last half of the $20^{\text {th }}$ century (and into the first decade of the $21^{\text {st }}$ ) Japan has experienced a general trend of low incarceration for both men and women. Except for a brief surge of incarceration during the 1980s, the general trend for male imprisonment has been downwards. The female trend has been much more erratic over time. While far fewer women are incarcerated than men, there is not a singular trend in female incarceration. Further, the trend in incarceration for stimulus drug offenses runs counter to the general incarceration trends for both men and women.

The strong intercorrelation of male and female stimulus admissions suggests that gender is not a strong influence in and of itself. The rates covary in a nearly perfect relationship. External social forces as well as cultural definitions of the serious nature of drug offenses are stronger factors in how stimulus offenders are treated within a criminal justice environment than their gender. Johnson (1996b) never directly compared male incarceration rates for stimulus offenses with women's rates, hence his conclusions that there was something unique within women's experiences. While indeed, during the period of his study (and this study) while overall incarceration rates fall there is an increase in stimulus incarceration at times. Yet this is not a gendered trend-male stimulus incarceration is increasing at the same time. The factors driving the trends explored by Johnson (1996b) were the product the nature of female offending. As discussed above, stimulus offenses account for a large portion of all female incarcerations. While they account for a large portion of male incarcerations as well, the proportions are not the same. Thus, while incarceration for normal offenses were declining in Japan, stimulus incarcerations were increasing. This effected women's prison populations more than men's because a larger portion of women are incarcerated for stimulus offenses than men. 
Double deviance explanations of Japanese's women's incarceration for stimulus offences would also suggest that Japanese women might experience a criminal justice backlash as a response to their attainment of some measure of socio-economic equity. Our provisional analyses suggest that this is not the case. In a period of Japanese history were women are experiencing increased equity (though are by no means on equal socio-economic footing) overall incarceration for women has been highly variable. No measures drawn upon to look for associations between increased female equity and female incarceration in general or incarceration for the violation of stimulus offenses specifically were significantly related. While our findings are by no means conclusive, we would suggest that if a segment of the female Japanese population were to experience the effects of a backlash within the criminal justice system it would be stimulus offenders, who constitute a large portion of all female inmates. Future work should be done to more precisely specify and examine potential relationships here.

The limitations of this study are many. Full data for all variables over the entire period of time were not available for analysis. This highly limited the types of analyses which we could perform. We had to use the number of new prison admissions per year for stimulus violations instead of the number of readmissions or a combination of the two. The number of readmissions for stimulus violation was not available for the full time period in a disaggregated form. As mentioned in the introduction, incarcerations are more likely for repeat offenders. Unfortunately we could not examine that trend or its association with our other variables. The data here are macro-level data; individual level data would allow for a finer examination of how socioeconomic forces intersect interest with incarceration decisions/experiences. For example, while we connected general economic shifts with stimulus incarceration effects, we cannot say if there are any individual level characteristics which predict stimulus incarceration. Perhaps with 
individual level data, we could uncover an 'evil woman' effect or some other set of relationships that will better explain variation in not only female but also male incarceration experiences. Also, we might be able to uncover differences between characteristics of men and women who use stimulus drugs.

In sum, we have shown that while there is a gender gap in terms of the numbers of men versus women who are incarcerated for stimulus drug violations, there does not seem to be a difference in the overall trend of men's and women's admissions to prison for stimulus drug offenses. Similar social factors seem to be influencing stimulus incarceration overall. In part, economic factors seem to play a role. While we did find relationships with female social status, we see them as artifactual and not likely to be casual. Much more work needs to be done on Japanese incarnation in general and stimulus violations specifically. We hope to have provided an overview of basic trends and general associations to stimulate future research, as much still needs to be done to fully understand the predictors and trends of Japanese incarceration. 


\section{References}

Chesney-Lind, M. and L. Pasko. 2004. The Female Offender: Girls, Women and Crime. Second edition. Thousand Oaks, CA: Sage.

Daly, K. 1994. Gender, Crime and Punishment. New Haven, CT: Yale University Press.

Japanese Ministry of Internal Affairs and Communications. Historical Statistics of Japan. Avaliable online at: http://www.stat.go.jp/english/data/chouki/index.htm. Last accessed, May 20th, 2009

Japanese Ministry of Justice. 2005. White Paper on Crime.

---- 2003. White Paper on Crime.

Johnson, D.J. 2002. The Japanese Way of Justice: Prosecuting Crime in Japan. Oxford, UK: Oxford University Press.

----- 1998. The organization of Prosecution and the Possibility of Order. Law and Society Review. 32(2): 247-308.

Johnson, E. H. 1996a. Japanese Corrections: Managing Convicted Offenders in an Orderly Society. Carbondale, IL: Southern Illinois University Press.

1996b. The paradox of Japanese women's rising imprisonment rate. Journal of Offender Rehabiliation. 24(1/2):61-87

Lambert, P. A. 2007. The political economy of postwar family policy in Japan: Economic imperatives and electoral incentives. Journal of Japanese Studies. 33:1. 1-28.

Miller, J and C,W. Mullins. 2006 Taking Stock: The Status of Feminist Theories in Criminology. In, F Cullen, J P Wright and K Blevins, editors. Taking Stock: The Status of Criminological Theory. Vol 15. Advances in Criminological Theory. Freda Adler and William Laufer, series editors. 217-49

Morley, P. 1999. The Mountain is Moving: Japanese Women's Lives. New York: New York University Press.

Ochiai, E. 1998. Decent Housewives and Sensual White Women-Representations of Women in Postwar Japanese Magazines. . In, E. Beauchamp, editor, Women and Women's Issues in Post Wolrd War II Japan. New York: Garland Publishing. 307-226.

Reiman, J. 2007. The Rich Get Richer and the Poor Get Prison: Ideology, Class and Criminal Justice. $8^{\text {th }}$ edition. Boston, MA: Pearson. 
Shelden, R. 2001. Controlling the Dangerous Classes: A Critical Introduction to the History of Criminal Justice. Boston, MA: Allyn and Bacon.

Stanley, A. 2007. Adultery, punishment and reconciliation in Tokugawa Japan. Journal of Japanese Studies. 33:2. 309-335.

US Department of Justice. 2006. Prison and Jail inmates at Midyear 2005.

Uno, K. S. The Death of "Good Wife, Wise Mother?". . In, E. Beauchamp, editor, Women and Women's Issues in Post World War II Japan. New York: Garland Publishing. 227-257.

Vavich. D A. 1998. The Japanese Women's Movement: Ichikawa Fusae: A Pioneer in Woman's Suffrage. In, E. Beauchamp, editor, Women and Women's Issues in Post World War II Japan. New York: Garland Publishing. 30-64.

Warr, M. 2002. Companions in Crime: The Social Aspects of Criminal Conduct. Cambridge, UK: Cambridge University Press.

White, Mary. 1998a. Home Truths: Women and Social Change in Japan. . In, E. Beauchamp, editor, Women and Women's Issues in Post Wolrd War II Japan. New York: Garland Publishing. 185-206.

--- 1998b. The Virtue of Japanese Mothers: Cultural Definitions of Women's Lives. . In, E. Beauchamp, editor, Women and Women's Issues in Post Wolrd War II Japan. New York: Garland Publishing. 267-281. 


\section{Figure 1}

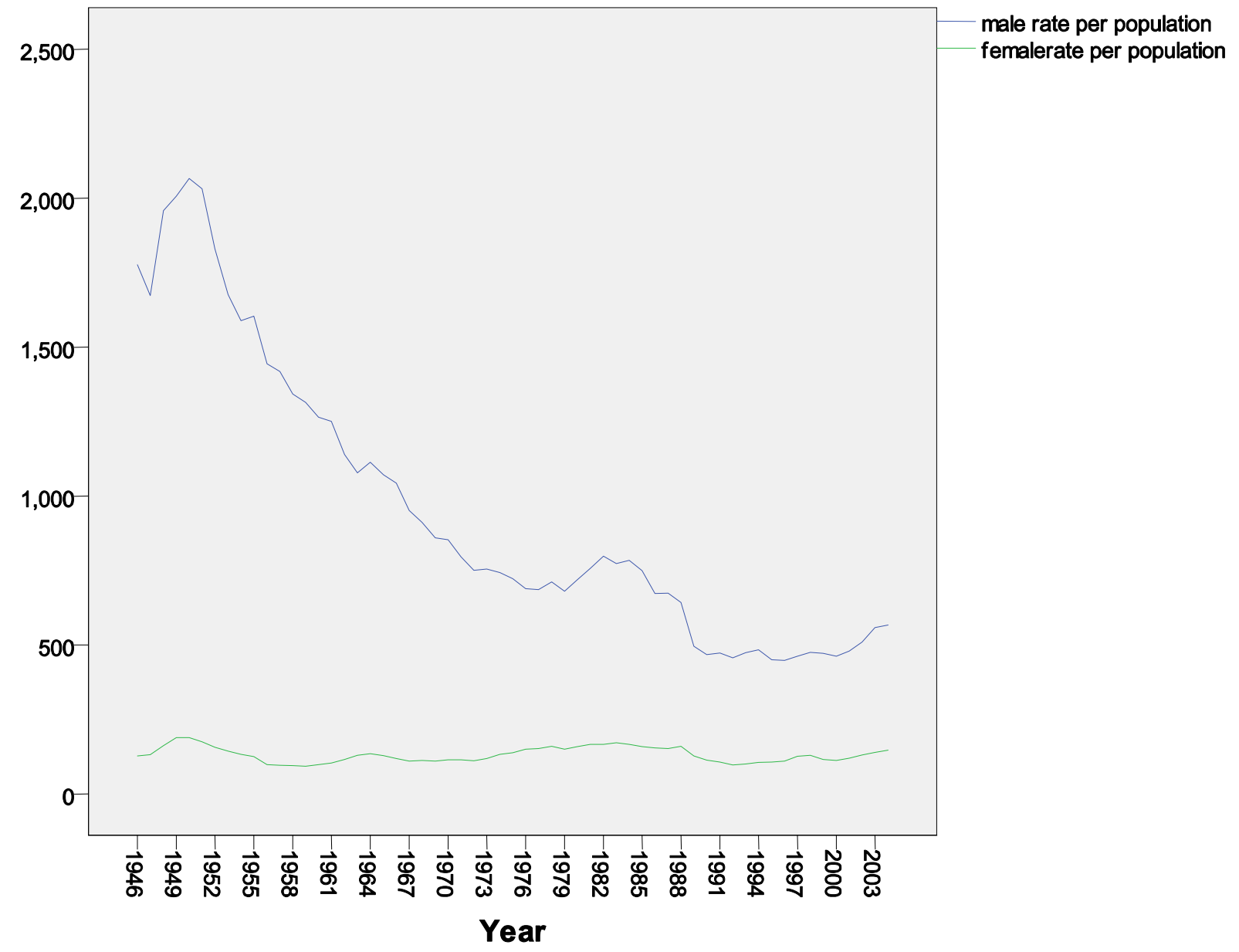

Figure 2 


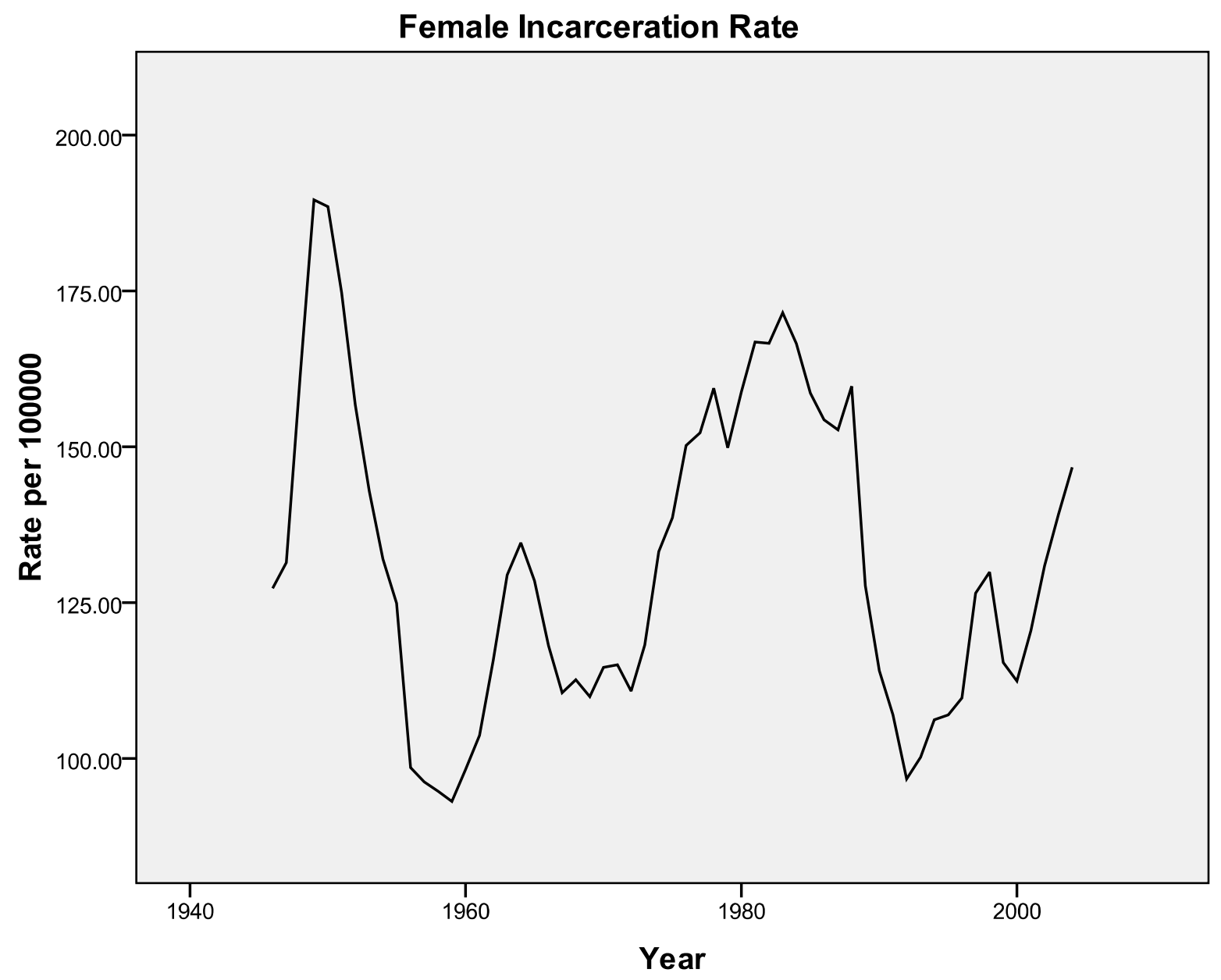

Figure 3 


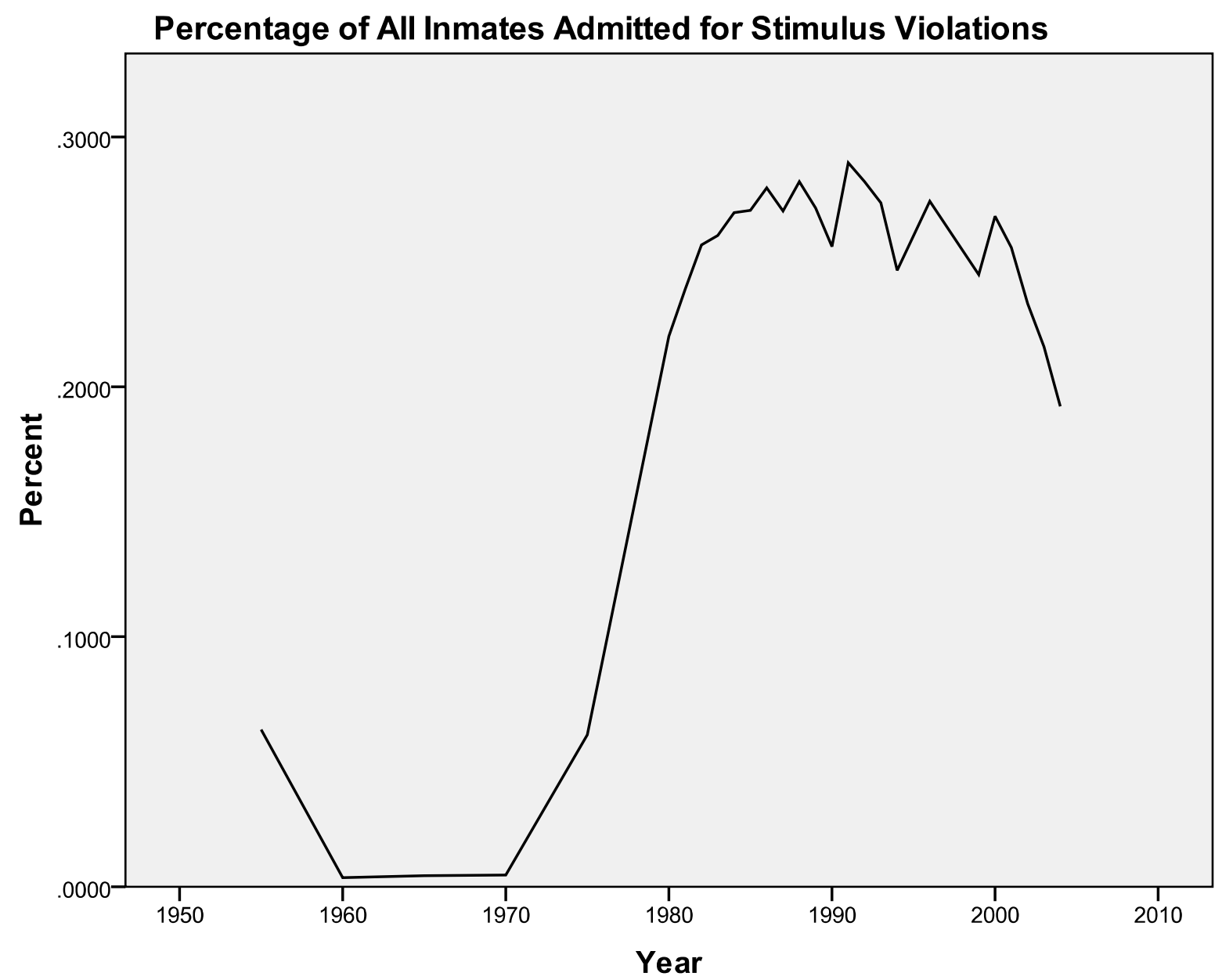

Figure 4 


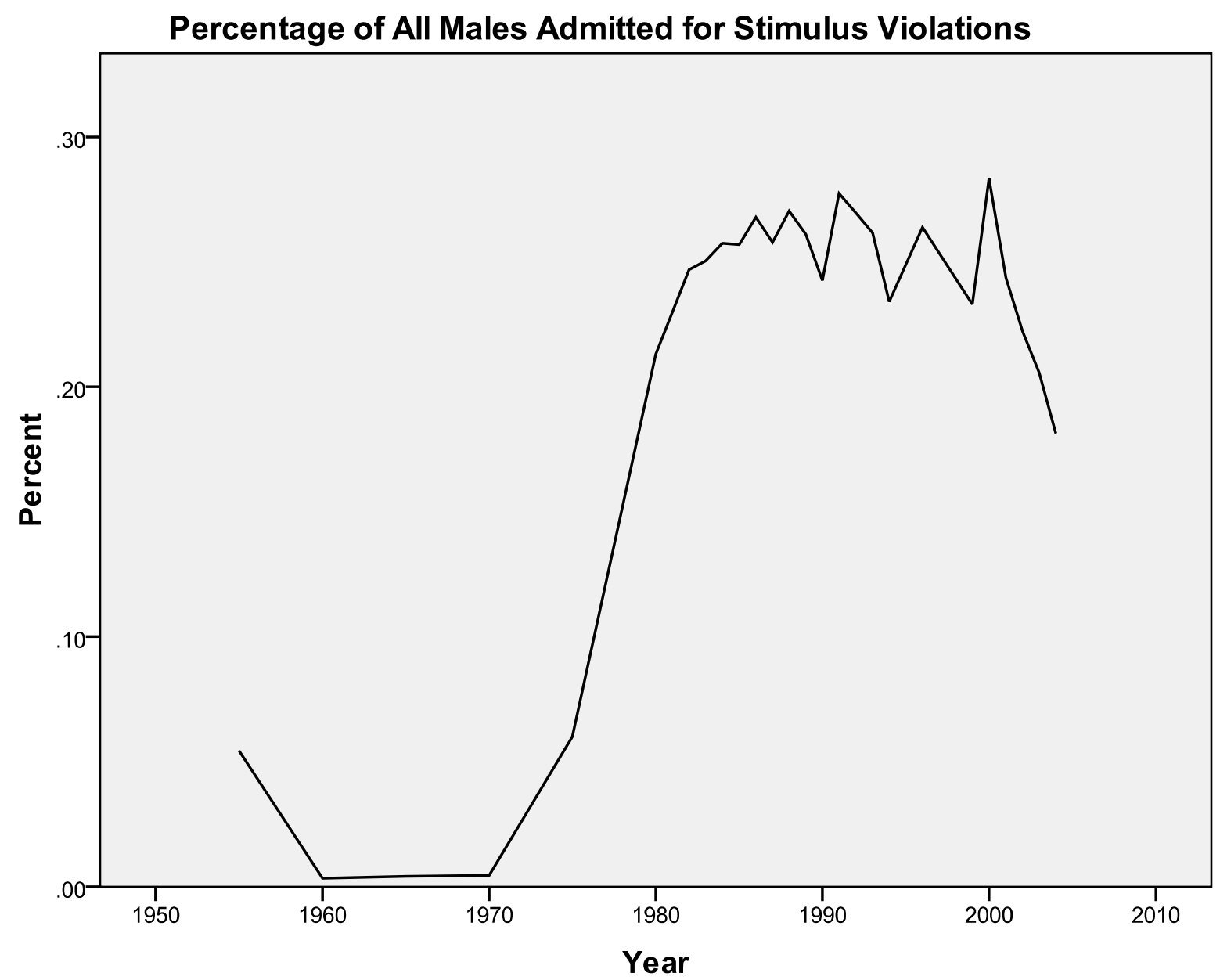

Figure 5 


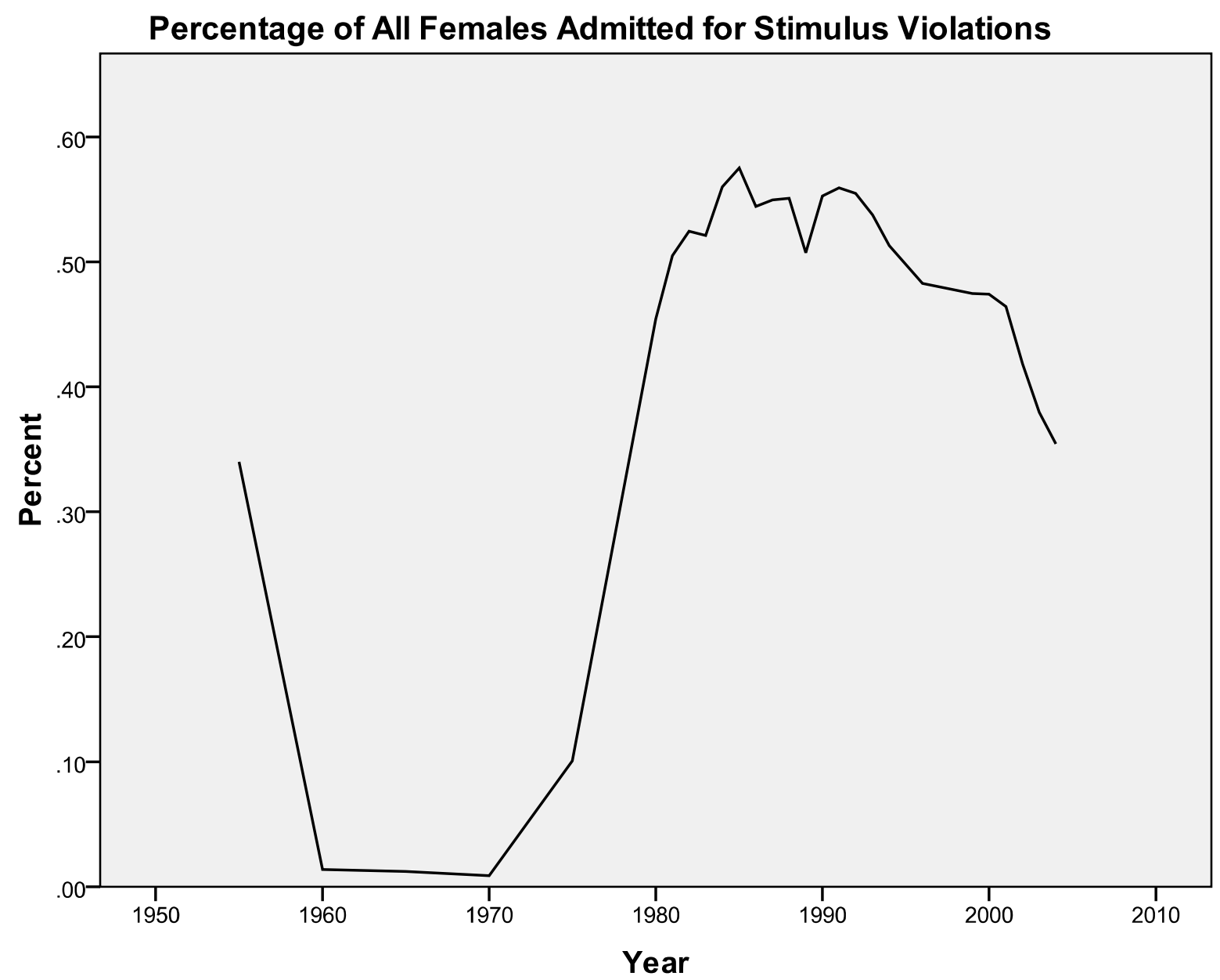

Figure 6 


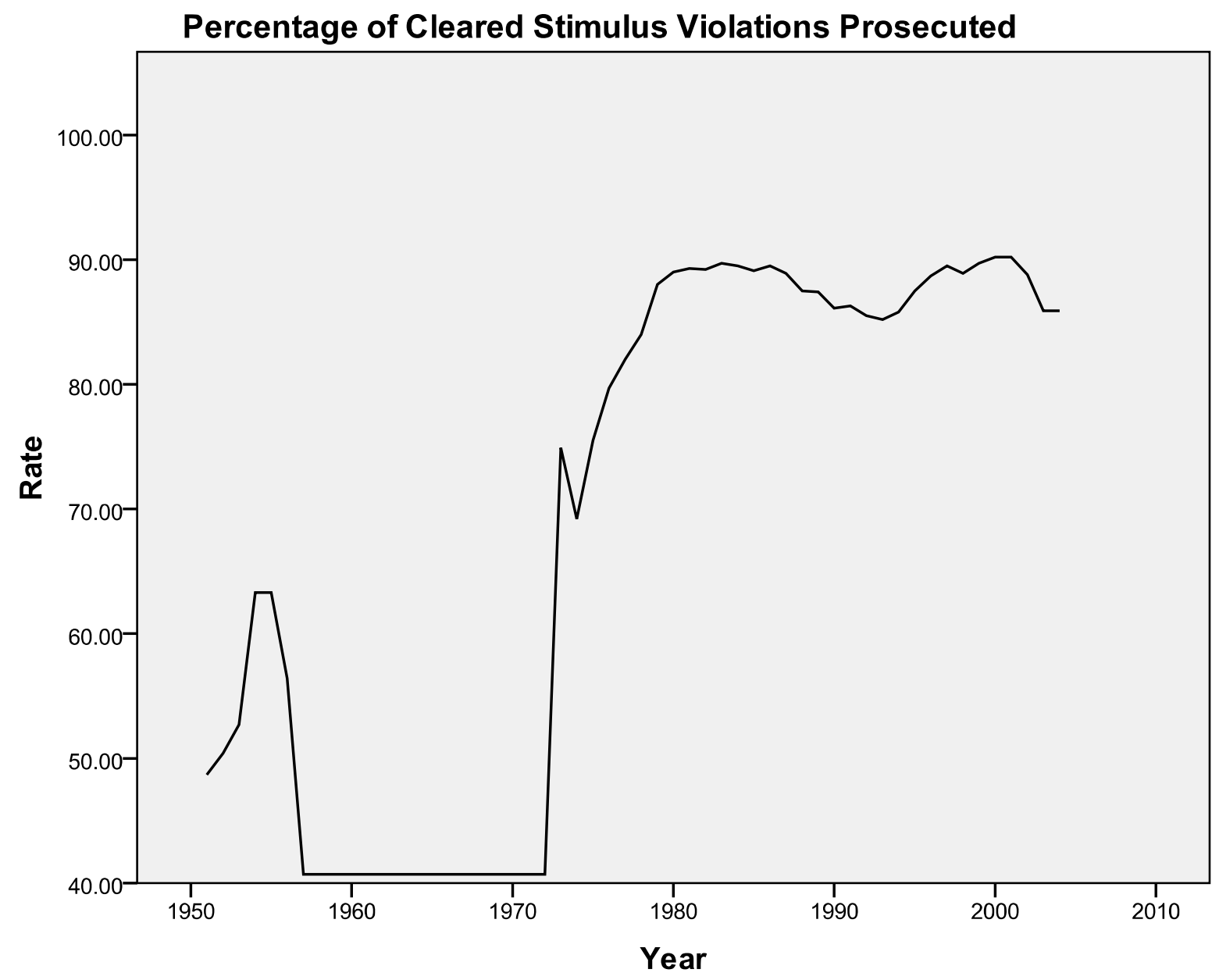


Table 1: Cor

\begin{tabular}{|c|c|c|c|c|c|}
\hline & & $\begin{array}{c}\text { male rate per } \\
\text { population }\end{array}$ & $\begin{array}{c}\text { femalerate per } \\
\text { population }\end{array}$ & males stim drugs & $\begin{array}{r}\text { female } \\
\text { dru\& }\end{array}$ \\
\hline male rate per population & $\begin{array}{l}\text { Correlation } \\
\text { Significance (2-tailed) } \\
\text { df }\end{array}$ & $\begin{array}{r}1.000 \\
0 \\
0\end{array}$ & $\begin{array}{r}.869 \\
.000 \\
16 \\
\end{array}$ & $\begin{array}{r}.829 \\
.000 \\
16 \\
\end{array}$ & \\
\hline femalerate per population & $\begin{array}{l}\text { Correlation } \\
\text { Significance (2-tailed) } \\
\text { df }\end{array}$ & $\begin{array}{r}.869 \\
.000 \\
16 \\
\end{array}$ & $\begin{array}{r}1.000 \\
. \\
0\end{array}$ & $\begin{array}{r}.839 \\
.000 \\
16 \\
\end{array}$ & \\
\hline males stim drugs & $\begin{array}{l}\text { Correlation } \\
\text { Significance (2-tailed) } \\
\text { df }\end{array}$ & $\begin{array}{r}.829 \\
.000 \\
16 \\
\end{array}$ & $\begin{array}{r}.839 \\
.000 \\
16 \\
\end{array}$ & $\begin{array}{r}1.000 \\
. \\
0\end{array}$ & \\
\hline female stim drugs & $\begin{array}{l}\text { Correlation } \\
\text { Significance (2-tailed) } \\
\text { df }\end{array}$ & $\begin{array}{r}.863 \\
.000 \\
16 \\
\end{array}$ & $\begin{array}{r}.821 \\
.000 \\
16 \\
\end{array}$ & $\begin{array}{r}.925 \\
.000 \\
16 \\
\end{array}$ & \\
\hline $\begin{array}{l}\text { percent of all females in } \\
\text { post-secondary ed }\end{array}$ & $\begin{array}{l}\text { Correlation } \\
\text { Significance (2-tailed) } \\
\text { df }\end{array}$ & $\begin{array}{r}-.112 \\
.659 \\
16 \\
\end{array}$ & $\begin{array}{r}-.177 \\
.483 \\
16 \\
\end{array}$ & $\begin{array}{r}-.348 \\
.157 \\
16 \\
\end{array}$ & \\
\hline $\begin{array}{l}\text { percent of all females in } \\
\text { university }\end{array}$ & $\begin{array}{l}\text { Correlation } \\
\text { Significance (2-tailed) } \\
\text { df }\end{array}$ & $\begin{array}{r}.237 \\
.343 \\
16 \\
\end{array}$ & $\begin{array}{r}.253 \\
.311 \\
16\end{array}$ & $\begin{array}{r}.136 \\
.590 \\
16\end{array}$ & \\
\hline $\begin{array}{l}\text { percentage of females in } \\
\text { assembly }\end{array}$ & $\begin{array}{l}\text { Correlation } \\
\text { Significance (2-tailed) } \\
\text { df }\end{array}$ & $\begin{array}{r}.156 \\
.538 \\
16 \\
\end{array}$ & $\begin{array}{r}.219 \\
.382 \\
16 \\
\end{array}$ & $\begin{array}{r}.135 \\
.592 \\
16 \\
\end{array}$ & \\
\hline $\begin{array}{l}\text { percentage of female labor } \\
\text { force participation }\end{array}$ & $\begin{array}{l}\text { Correlation } \\
\text { Significance (2-tailed) } \\
\text { df }\end{array}$ & $\begin{array}{r}-.515 \\
.029 \\
16 \\
\end{array}$ & $\begin{array}{r}-.670 \\
.002 \\
16 \\
\end{array}$ & $\begin{array}{r}-.540 \\
.021 \\
16 \\
\end{array}$ & \\
\hline $\begin{array}{l}\text { percentage of women totally } \\
\text { unemployed }\end{array}$ & $\begin{array}{l}\text { Correlation } \\
\text { Significance (2-tailed) }\end{array}$ & $\begin{array}{r}.670 \\
.002\end{array}$ & $\begin{array}{r}.690 \\
.002\end{array}$ & $\begin{array}{l}.554 \\
.017\end{array}$ & \\
\hline
\end{tabular}




\begin{tabular}{|c|c|c|c|c|}
\hline & df & 16 & 16 & 16 \\
\hline \multirow{3}{*}{$\begin{array}{l}\text { percent of men totally } \\
\text { unemployed }\end{array}$} & Correlation & .614 & .653 & .524 \\
\hline & Significance (2-tailed) & .007 & .003 & .026 \\
\hline & $\mathrm{df}$ & 16 & 16 & 16 \\
\hline
\end{tabular}

